\title{
The Transformation of Ownership Policy and Structure in Sweden: Convergence towards the Anglo-Saxon Model?*
}

\author{
by \\ Magnus Henrekson ${ }^{1 *}$ and Ulf Jakobsson ${ }^{2}$ \\ SSE/EFI Working Paper Series in Economics and Finance No. 469 \\ September 19, 2002
}

\begin{abstract}
We investigate the dramatic transformation of ownership policies and ownership structure in Sweden during the postwar period. After WWII, Swedish ownership policies were guided by a socialist vision where the ultimate goal was abolition of private ownership. These policies came to an end in the early 1980s. Since then a large number of Swedish firms have been acquired by foreign owners or merged with foreign firms and the foreign ownership share on the Swedish Stock Exchange has increased rapidly. A central question is whether this fast transformation is merely a logical consequence of current globalization, or whether this tendency has been reinforced by economic policies vis-à-vis the business sector in Sweden. We show that until the late 1980s, Swedish economic policy - aimed at discouraging wealth accumulation among households and favoring institutional ownership and debt financing - effectively precipitated the rapid takeover of the Swedish business sector by foreign owners that gained momentum in the 1990s. Policy measures intended to create a system of "capitalism without capitalists" can be said to have "packaged" large Swedish corporations in terms of ownership and financing structure, so that foreign takeover was facilitated. The article ends with a discussion as to whether the dramatic change in ownership structure in the Swedish business sector may result in the demise of the old corporatist model of industrial relations, giving way to a new trend towards a liberal market economy of the current Anglo-Saxon variety.
\end{abstract}

JEL Classification: M13, N24, O38, P16.

Keywords: Corporatism, Entrepreneurship, Industrial policy, Ownership policy, Ownership structure, Swedish Model.

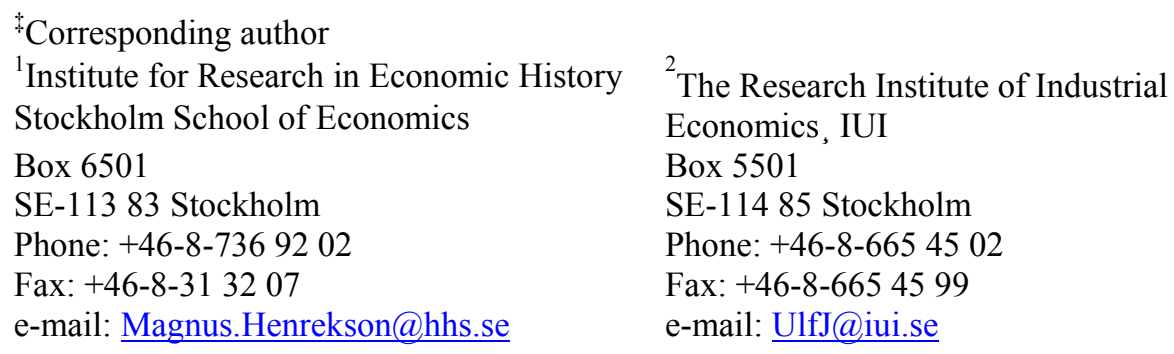

\footnotetext{
* An earlier version of this paper was presented at the conference Small States in World Markets - Fifteen Years Later, University of Gothenburg, September 27-29, 2001. We thank Robin Douhan and Malin Hübner for research assistance and Johan Fall, Mattias Ganslandt, Assar Lindbeck, Per-Martin Meyerson, Erik Norrman, Julie Sundqvist and two anonymous referees for constructive comments and suggestions. Magnus Henrekson gratefully acknowledges financial support from the Jan Wallander and Tom Hedelius Foundation.
} 


\section{Introduction}

From the 1960s until the late 1980s, the Anglo-Saxon model of capitalism was called into question. It was easy to point out that many countries, such as Germany, Sweden and Japan, seemed to outperform the United States and other countries characterized by more unbridled market capitalism. The 1990s, however, entailed a resurgence of the U.S. relative to other rich countries in terms of economic growth, job creation and technological leadership.

This change in the previous trend has stirred a lively debate as to whether we are now witnessing a general convergence towards the Anglo-Saxon model. Or, to use the terminology of Kitschelt et al. (1999), is there a general movement away from various systems of coordinated market economies (CMEs) towards a more uniform system of a liberal market economy (LME)? Observers such as Freeman (2000), Garrett (2000) and Kitschelt et al. (1999) claim that Katzenstein's (1985) conclusion still holds, i.e., despite current trends towards increased globalization and economic integration, there is still considerable leeway for individual countries to retain their distinctive politico-institutional character. In contrast, there are other scholars such as Feldstein (2000), Hansmann and Kraakman (2000) and Audretsch and Thurik (2000) who project that the economic structure in virtually all countries is converging towards the Anglo-Saxon model of capitalism, albeit at different rates. ${ }^{1}$

The discussion about convergence was also lively in the 1950s and early 1960s, but with a distinctly different flavor. During the early postwar period, government influence expanded in most industrial countries, accompanied by high optimism regarding the state's potential to control the economy. These circumstances prompted Tinbergen (1961) to formulate the hypothesis that eastern and western economies would converge towards each other and eventually meet at a point where the degree of socialism and state control in western economies had achieved a considerably higher level than during the 1960s.

The Swedish case provides an instructive illustration of this debate. Among western countries, Sweden led the way towards Tinbergen convergence. But once the trend had shifted, Sweden became one among several countries whose business sector underwent the most rapid globalization. The purpose of this article is to analyze these two very different phases in the Swedish economy. A question of particular interest is why such an abrupt shift

\footnotetext{
${ }^{1}$ Popularly this view is often referred to as "the Washington Consensus". A typical formulation of this process is the following: "Thus, despite the meaningfully different views initially held of the way the world does, and should work, powerful global competitive forces appear for now to be driving the economic and legal paradigms of many nations into closer alignment around a more competitive market capitalism." The quote is from a speech by Alan Greenspan, "Global Economic Integration: Opportunities and Challenges", given at a symposium sponsored by the Federal Reserve Bank of Kansas City, Jackson Hole, Wyoming on August 25, 2000.
} 
in the trend occurred in the early 1990s. Here, we attempt to trace the background and provide an explanation of this phenomenon. The shift in the trend which took place in Sweden was obviously part of overall international development. But, as we shall see, domestic developments and domestic economic history also had important effects. We focus on one aspect of Swedish economic policy, i.e., ownership policy, which is central to the ideas of convergence discussed here. We also consider the strong links between ownership policy and other areas of economic policy.

In section 2 we briefly characterize the development of ownership structure in postwar Sweden. Sections 3-4 explore various aspects of the ownership policy in effect from 1945 to the mid-1980s. We address the ideological foundations for the prevailing views on ownership and the importance of large vs. small firms for economic growth and renewal (section 3 ). In section 4 we document the economic policy instruments used by the Swedish government. In section 5 we document that the effects of the far-reaching policies pursued were not only as intended, but also as could be expected in accordance with basic economic theory. Next, we analyze the turning point and the conditions which precipitated it (section 6). Section 7 contains an analysis of the development since the mid-1980s, characterized by a rapid increase in the foreign ownership share of the Swedish private sector. Section 8 concludes.

\section{A Stylized Representation of Swedish Ownership Policy and Structure}

The ownership structure of Swedish firms has undergone dramatic transformation during the postwar period. The shift in the trend may be divided into two phases (in section 6 this will be examined in detail). The first extended from 1945 until the mid-1980s. Phase I was characterized by a substantial decline in household ownership. After having accounted for 80 percent of the total value of listed companies in the late 1940s, the share of household ownership in the business sector fell to approximately 20 percent by the end of the period. Institutional ownership increased to a corresponding degree. During this phase, foreign ownership was limited by legislative impediments to acquisition of property and capital in Sweden. These rules were phased out during the 1980s and early 1990s.

Repeal of these laws coincided with the transition to Phase II and initiated a rapid increase in foreign ownership of Swedish firms. Between 1989 and 2001, the share of foreign ownership in Swedish listed companies rose from 7 to 43 percent (Sundin and Sundqvist 2001). According to World Investment Report (UNCTAD 1999), direct investments measured as a share of domestic gross investments were larger in Sweden than in any other country 
worldwide during the period 1995-97. In 2002, there was still no indication of a break in this trend. Evidence of this development includes the large number of takeovers of Swedish firms, mergers between Swedish and foreign companies, as well as relocation of headquarters and management from Sweden to other countries.

In a political perspective, the sharp contrast between these two phases seems paradoxical. During Phase I, ownership policy was shaped under the influence of a long-run socialist vision, embedded in the ideology of the Social-Democratic Party. A clear-cut pattern in this policy was to undermine individual ownership. The explicit objective was some kind of collective/ public ownership of the business sector (see section 3). This period came to a definitive end when the Swedish wage-earner fund scheme, set up in the early 1980s, was abolished in 1992.

Phase II witnessed rapid takeover of the Swedish business sector by foreign owners. Today, it appears as if the original socialist vision has never been more remote. This political transformation is not easily explainable. The Social-Democratic Party (SAP) has been the dominant force in Swedish politics throughout the postwar period, and the policies pursued during both phases were supported by a majority in Parliament. Indeed, the radical transformation of ownership policy has never been subjected to serious ideological debate. The Government has upheld the growth of foreign ownership primarily in terms of liberal arguments. But this has not prevented the SAP from claiming - most recently in the draft of its new platform (2001) - to be an anti-capitalist party. An outline of ownership policy and structure during Phases I and II is shown in Table 1.

Given the nearly nonexistent debate in Sweden, it might be tempting to attribute the dramatic transformation of ownership policy to a change in global conditions. During Phase I, government influence expanded in most industrial countries, accompanied by high optimism regarding the state's potential to control the economy, which among other things resulted in the Tinbergen (1961) convergence hypothesis. In the late 1960s and throughout most of the 1970s, many observers - and members of the Swedish political elite in particular - perceived Sweden as a leader in this respect among western countries.

As of the late 1970s, however, political developments already contrasted sharply with Tinbergen's predictions. The communist economies collapsed, and economic policy in western countries began to take on an increasingly liberal orientation. Privatization and deregulation were high on the political agenda in all industrialized countries.

The shift in the trend in ownership policy which has taken place in Sweden coincides with this overall pattern. As we will document in greater detail below, Sweden led the way 
among western countries in realizing Tinbergen's convergence hypothesis. But once the trend shifted, Sweden became one of those countries whose business sector underwent the most rapid globalization.

Table 1 Stylized Outline of Ownership Policy and Structure in Sweden during the Postwar Period.

\begin{tabular}{|c|c|c|}
\hline & Phase I (1945-1985) & Phase II (1985-) \\
\hline $\begin{array}{l}\text { Ideological } \\
\text { superstructure }\end{array}$ & $\begin{array}{l}\text { Long-run vision of a socialist } \\
\text { economy; Marx, Schumpeter, } \\
\text { Wigforss. }\end{array}$ & $\begin{array}{l}\text { Ambiguous combination of } \\
\text { market liberalism, adjustment to } \\
\text { EU and anti-capitalism. }\end{array}$ \\
\hline Policy in practice & $\begin{array}{l}\text { Aimed at discouraging } \\
\text { individual wealth } \\
\text { accumulation, stimulating } \\
\text { institutional ownership, } \\
\text { favoring large companies, } \\
\text { impeding small and new firms. } \\
\text { Strong obstacles to foreign } \\
\text { ownership. }\end{array}$ & $\begin{array}{l}\text { Deregulation and greater market } \\
\text { orientation. Removal of } \\
\text { obstacles to foreign ownership. } \\
\text { Fiscal discrimination of } \\
\text { Swedish ownership. }\end{array}$ \\
\hline $\begin{array}{l}\text { Resulting } \\
\text { ownership } \\
\text { structure }\end{array}$ & $\begin{array}{l}\text { Strong increase in institutional } \\
\text { ownership and corresponding } \\
\text { decline in individual } \\
\text { ownership. }\end{array}$ & $\begin{array}{l}\text { Strong increase in international } \\
\text { ownership and corresponding } \\
\text { decline in Swedish institutional } \\
\text { ownership. }\end{array}$ \\
\hline
\end{tabular}

\section{Ideological and Political Background}

The goal of socialism was certainly distant until the 1970s. In the early ideological discussion after the war there was, however, no ambiguity on the question whether the goal would eventually be reached. In Trade Unions and Full Employment (LO 1953), a major policy document from the Swedish Confederation of Trade Unions (LO), one finds a clear emphasis on collective/and or state ownership. In this respect the document largely reflected the doctrine of the leading Social-Democratic ideologist Ernst Wigforss, Minister of Finance in 1925-26 and 1932-49. He maintained that, in the long run, the large industrial corporations had to be converted into "social enterprises without owners". In such enterprises individuals could still be shareholders, but the shareholders would no longer be residual claimants. Moreover, wages should be set in wage negotiations, dividends should be tied to the level of interest rates in capital markets and all "excess profits" should remain within the companies.

The industrial policies actually pursued did promote development of the economy in accordance with the visions of the LO and Wigforss. Until the mid-1970s, however, very few 
direct measures were implemented to transfer ownership of firms from private hands to the government, although some steps were taken - especially in mining, steel and forestry - to increase direct state ownership of the corporate sector.

This policy has been termed "the historical compromise" (Korpi 1982). The industrial elite acknowledged and more or less accepted that by virtue of their political strength, the Social Democrats would use their political power to implement far-reaching welfare reforms, while the labor movement would abstain from socializing the industrial sector. It would have been very difficult to develop this culture of compromise and negotiations between different elites (Steinmo 2001; Katzenstein 1985) without the predominance of a few large firms and even fewer ownership groups (Reiter 2001). From a Social-Democratic perspective, however, this historical compromise must have seemed like a temporary social contract. Along with industrial policy designed to adhere to the ideas of the LO and Wigforss, the notion of "the third step of socialism", i.e., "democratization" of ownership of Swedish industry, had many advocates within the labor movement. ${ }^{2}$

In a comprehensive historical study of the LO, Johansson and Magnusson (1998) describe how the trade union movement gradually developed a vision of "capitalism without capitalists". They claim that this vision is crucial, because it constitutes

...the link uniting collectivism and market dynamics. As a result, capitalism can be salvaged without requiring powerful owners or capitalists. Redistribution of income can co-exist with high profits in the most dynamic firms (p. 121).

This idea was transformed into more tangible concepts in the mid-1970s. Explicit demands for increased collective ownership on a much grander scale were voiced at the 1976 LO Congress, where a plan was introduced for an inexorable transfer of ownership from private hands to collective "wage-earner funds"; see Meidner (1978). This may be interpreted as a concrete plan for materializing Wigforss' original vision to convert large corporations into "social enterprises without owners". We will come back to the details and the implementation of this proposal in subsection 4.3. Here we will continue with an analysis of the background and motivation for the policies that precipitated the wage-earners fund proposal.

In Table 1 we indicated a number of important features of the economic policy during the first phase of the postwar period. As we shall see they all facilitated a transformation of the Swedish economy to socialism. Even if the policies were shaped within the framework of a long-term socialist vision, they should not be seen as part of a fixed plan to turn Sweden into a socialist country. The policies could also be motivated by more practical short- and 
medium-term objectives, such as a more egalitarian distribution of income and wealth. One could also argue that they served to strengthen the power of the LO and the SocialDemocratic party.

The first feature of the policy was discouragement of individual wealth accumulation. Obviously this was a policy line that eventually would facilitate a transformation to socialism. The existence of individual wealth is after all a prerequisite for a capitalist private-ownership economy. The absence of individual wealth in broad groups of society could also be expected to erode the general political support for capitalism. Policies discouraging private wealth accumulation could also be entirely motivated on egalitarian grounds. By discouraging private wealth formation, and by taxing existing wealth, the distribution of individual wealth was equalized. The policies could also be seen as an effort to create a society where people did not engage in "bourgeois" activities like cultivating their individual wealth and starting up their own enterprises. Or in the words of the Social Democratic ideologist Alva Myrdal: "The people should not fall victim to a moral of private happiness." In such a society the room for the bourgeois parties would be diminished.

The second feature is a general favouring of large companies relative to small and new firms. Many writers have seen the connection between a collectivist society and an economy based on large firms, notably Karl Marx and Joseph Schumpeter. In our context the ideas of Schumpeter in this respect are illuminating. Schumpeter (1942) saw the declining economic importance of the entrepreneur as one of the major forces in the transformation from capitalism to socialism. Schumpeter claimed that by means of modern techniques and modern modes of organization, the innovation process would become increasingly automated. Innovations would no longer be associated with the efforts and brilliance of an individual.

Schumpeter maintained that entrepreneurs, along with a large number of selfemployed, constituted the requisite political base for a capitalist society. The numerous members of the small-business community formed the backbone of the bourgeoisie, without which capitalism would lose both its institutional base and its political legitimacy. But as production gradually became increasingly concentrated to a few large corporations, small firms would wane in importance. As a result, modern capitalism would undermine its own political and institutional base. Schumpeter also agreed with Marx that the increased concentration of production to large firms would go hand in hand with greater concentration of ownership. Eventually, popular resistance to socialization of the means of production would vanish, since the general public would consider the difference between the state and

\footnotetext{
${ }^{2}$ The first two steps were universal suffrage and co-determination (Pontusson 1992).
} 
the few remaining giant corporations to be negligible. After the extinction of the bourgeoisie, there would be no influential group left in society to identify with and actively defend capitalism. Hence, capitalism was bound to be superseded by socialism as the economic system in mature industrialized economies.

From our perspective, the theories of both Marx and Schumpeter are relevant. ${ }^{3}$ At the dawn of the postwar period, firm structure in Sweden was characterized by a predominance of large firms and highly concentrated ownership (Lindgren 1953).

According to Marx and Schumpeter in his later writings, small firms and entry of new firms were of marginal importance in the advanced capitalist economy. Wigforss hardly found this disquieting; this state of affairs would instead facilitate the desired collectivization and socialization of the productive capital stock. Furthermore, Wigforss (1952, p. 125-126) found it essential to focus on large industrial corporations for non-economic reasons:

Here is where the adversarial relationship between owners and employees is most fundamental, and where the collective form of ownership and management can most easily be used as a means to achieve more equality, freedom and solidarity. Their crucial importance for the national economy and the standard of living of the people is self-evident.

The policies of favouring large firms could also be motivated from a more short-term perspective. First, large firm predominance was a necessary requirement for the realisation of the vision of "capitalism without capitalists". An important feature of this vision was the idea that within this framework redistribution of income could be combined with a dynamic corporate sector. As already noted the predominance of large firms was also a necessary condition for the culture of compromise and negotiations that was an important part of the Swedish Model as developed by the Social Democrats.

One did not, however, at the time have to be a socialist or even a Social Democrat to favour large-scale production in large industrial corporations. Swedish corporate culture was certainly dominated by the people in the top echelons of the large Swedish corporations. It was also easy to find inspiration from prominent social scientists in other countries. In the 1950s and 1960s, probably the most influential thinker on these counts was John Kenneth Galbraith $(1956,1967)$. Galbraith forcibly argued that in a modern industrial society, innovative activity as well as improvements in current products and production processes could be carried out most efficiently within the realm of the large industrial corporation. Individual efforts, and hence individual incentives, had dwindled in importance. Galbraith

\footnotetext{
${ }^{3}$ The relevance of Schumpeter's theories in a Swedish context is further explored in Henrekson and Jakobsson (2001), and the relevance of Marx's theories has been stressed by Hernes (1991).
} 
thereby provided an important rationale for an economic policy favouring large corporations that was accepted in much wider circles than the Social Democratic Party.

A third feature of the overall policy was the favouring of institutional ownership. Obviously, this policy is very close to the Wigforss vision of "ownerless" companies. It could also be seen as a natural way of obtaining wealth accumulation without a more unequal individual wealth distribution. It could also be seen as a means of strengthening the political sphere in relation to the sphere of capitalists. Many of the institutions are at least indirectly under political control.

A seemingly paradoxical feature of Phase 1 in the postwar period is the fostering of further concentration of private ownership. The relative power of the wealthy few was even more enhanced by very weak protection of minority shareholders (Agnblad et al. 2001). By allowing shares with different voting rights and pyramiding Sweden was together with Switzerland extreme when it came to deviation from the Anglo-Saxon one share-one vote model in the stock-market (David and Mach 2002).

This fits into the Marxian picture of a small and well-defined class of capitalists and a large and equally well-defined class of wage-earners. In terms of the long-term socialist vision it is obviously an easier task to remove a small group of capitalists from the economic scene than a large one. The legitimacy and the political backing for capitalism is obviously is diminished with a shrinking number of capitalists.

On a more practical level, various writers have underlined the importance of a concentration of ownership as a prerequisite for the Swedish model of bargaining and compromises between the different elites (Katzenstein 1985). It is also a general observation that weak minority protection of shareholders is a common feature in countries with strong worker protection (Hall and Soskice 2001; Fehn and Meier 2001). The Swedish pattern fits very well into this picture. The relatively strong position of the well-established capitalists could thus be seen as an implicit part of the Swedish historical compromise. A government commission has also pointed out that trade unions explicitly favor concentrated ownership in large firms since " the existence of one strong owner (could) facilitate trade union activities." (SOU 1986:23, p. 143)

The last policy feature was the strong obstacles to foreign ownership. Until the mid1980 s, the issue of foreign ownership was negligible in the ideological debate. From a SocialDemocratic point of view, it is obvious that a sizeable foreign-ownership share of Swedish industry was not compatible with the visions of the LO and Wigforss. In retrospect, it is also difficult to identify any other groups that systematically argued in favor of lowering the 
threshold for foreign ownership. Neither pro-market economists nor the nonsocialist opposition regarded this as an important issue. Thus, the regulatory measures protecting domestic owners were hardly debated at all while they were in place - they seem to have been taken for granted. It is therefore all the more surprising that the lifting of these regulations also came to be taken for granted.

\section{Economic Policy}

As a basis for determining the effects of ownership policies in Sweden, we need to document the tax and capital-market policies implemented between the 1950s and the 1970s. As shown

in this section, such policies were well in line with the visions spelled out by Wigforss and the LO in the 1940s and 1950s. In the third subsection the wage-earner fund proposal is analyzed in the context of the ownership policies of Phase 1.

\subsection{Tax Policies}

A central element of Social-Democratic economic policy was to discourage wealth accumulation at the individual level. One important instrument used to attain this goal was and still is - wealth taxation, which has largely adhered to the same principles throughout the postwar period. The amount exempt from wealth taxation has been adjusted for inflation roughly every five years. In 2000, wealth tax was levied at a rate of 1.5 percent of a household's taxable wealth exceeding SEK 900,000. The tax rate has been reduced since the mid-1980s. At that time the maximum tax rate was 3 percent.

The rules for assessing taxable wealth in the business sector are particularly important in the context of our analysis. Until the late 1970s taxable wealth amounted to 100 percent of the net worth of unlisted companies. As of 1992, there is no wealth tax on unlisted shares and the net worth of companies. As regards listed shares, 100 percent of the market value constituted taxable wealth until the early 1990s. This was reduced to 80 percent in order to avoid paying wealth tax on the deferred tax on unrealized capital gains. In practice, these rules resulted in very high real rates of wealth taxation on individually owned corporate assets in the 1970s and 1980s. The wealth tax was not deductible at the company level, so that funds 
required to pay the wealth tax were first subjected to the mandatory payroll tax and the relevant marginal income tax rate. ${ }^{4}$

On the other hand, capital gains taxation was designed so that it became exceptionally advantageous for individual owners to sell their firms. Until 1976, the taxation of long-term (> 5 years) realized capital gains on shares and the sale of partnerships was negligible.

Between 1976 and 1990, 60 percent of nominal capital gains were exempt from taxation for assets held more than two years, while 100 percent of nominal capital gains were subject to taxation for assets held less than two years.

As of 1991, capital gains are taxed as capital income at a flat rate of 30 percent. All nominal capital gains are taxed. For unlisted firms, where the owners themselves are active in the firm, the capital gains tax is higher. Typically it is on the order of 43 percent. Until 1990, dividends were subject to the owner's marginal tax rate on the order of 80-85 percent and before that a corporate tax rate of roughly 55 percent had been levied (see Davis and Henrekson 1997 for details). Thus, we note that the combined effect of taxation on capital gains, wealth, profits and dividends forcibly led individuals away from the ownership of firms before the 1990/91 tax reform.

Prior to the comprehensive tax reform in 1990/91, Swedish tax policy greatly disfavored new, small and less capital-intensive firms, while large firms and institutional ownership were highly favored. During an extended period of time, for three decades beginning in the early 1960s, there were extreme differences in taxation for different sources of finance and ownership categories: (i) debt was given the most, and issues of new shares the least favorable treatment; (ii) households/individuals were taxed substantially more heavily than other owner categories. From some point in the 1960s until 1990 more than 100 percent of the real rate of return was taxed away for a household buying a newly issued share. ${ }^{5}$ To provide a sense of the magnitude of the distortions caused by the Swedish tax system, Table 2 lists effective marginal tax rates for different combinations of ownership and sources of finance. Three categories of owners and sources of finance are identified, and the effective marginal tax rate was calculated assuming a pre-tax real rate of return of 10 percent. A negative number means that the real rate of return is greater after than before tax. The distortive traits of the system were most prominent around 1980. Tax rules benefiting debt financing relative to equity financing and institutional relative to individual ownership, systematically favored large, real-capital-intensive, publicly traded and well-established firms.

\footnotetext{
${ }^{4}$ Typically 7 kronor had to be withdrawn from the firm for every krona paid in wealth tax.

${ }^{5}$ This outcome was the result of a combination of highly distortive tax rates and a high rate of inflation.
} 
This encouraged capital accumulation and investments in existing firms without creating conditions conducive to wealth formation at the individual level.

Table 2 Effective Marginal Tax Rates for Different Combinations of Owners and Sources of Finance, 1980, 1994 and 2001 (10\% real pre-tax rate of return at actual inflation rates).

\begin{tabular}{lrrr}
\hline & Debt & New share issues & Retained earnings \\
\hline 1980 & & & \\
Households & 58.2 & 136.6 & 51.9 \\
Tax exempt institutions & -83.4 & -11.6 & 11.2 \\
Insurance companies & -54.9 & 38.4 & 28.7 \\
1994 & & & \\
Households & & & \\
Tax exempt institutions & $32.0 / 27.0 \dagger$ & $28.3 / 18.3 \dagger$ & $36.5 / 26.5 \dagger$ \\
Insurance companies & -14.9 & 21.8 & 21.8 \\
& 0.7 & 32.3 & 33.8 \\
Hool & & & \\
Tax exempt institutions & & & \\
Insurance companies & $29.7 / 24.7 \dagger$ & $61.0 / 51.0 \dagger$ & $44.1 / 34.1 \dagger$ \\
& -1.4 & 23.6 & 23.6 \\
\hline
\end{tabular}

$\dagger$ Excluding wealth tax; the wealth tax on unlisted shares was abolished in 1992.

Notes: The calculations conform to the general framework developed in King and Fullerton (1984). The average holding period is assumed to be 10 years.

Source: Calculations provided by Jan Södersten; see Södersten $(1984,1993)$.

In a series of reforms between 1985 and 1994, the distortions in tax wedges across different owners and sources of finance were to a large extent evened out. After 1995, the differences in tax wedges increased once again, largely following the previous pattern. However, the tax system at the beginning of the $21^{\text {st }}$ century is very far from the extreme situation prevailing before the 1990/91 tax reform.

The distortions in the tax system in Phase I did not have much of an impact on the relative situation of Swedish vs. foreign owners, since foreign ownership was subjected to restrictions. But when the restrictions on foreign ownership were lifted in Phase II, the focus shifted to the relative treatment of foreign and Swedish owners. The new system represented a significant step towards neutrality among Swedish owners. However, the tax burden on Swedish individual ownership remained heavier than the tax burden on individual ownership in most other countries. Following deregulation, this difference became economically significant.

The fact that the tax burden varies in accordance with the tax rules in the respective owner's home country has to be taken into account when analyzing the new situation. It is 
probably reasonable to assume that roughly the same tax wedges as in Sweden apply to taxexempt institutions. Table 3 reports a representative tax calculation for different owners using the 2001 tax code. It is evident that the Swedish tax system greatly favors foreign ownership relative to Swedish individual ownership. The more favorable tax situation of foreign owners implies that their pre-tax required rates of return can be lower than those of Swedish owners (except for Swedish tax-exempt institutions), i.e., that foreign owners, ceteris paribus, can pay a higher price for Swedish corporate assets than Swedish (rival) owners. As is clear from Table 4 , a large number of countries had a lower level of taxation of shareholdings for individuals than Sweden in 2000.

Table 3 Taxation of Dividends for Different Owner Categories according to the 2001 Tax Code - Investment of SEK 10,000 and 10\% Return Paid as a Dividend.

\begin{tabular}{lrrrr}
\hline & $\begin{array}{r}\text { Swedish } \\
\text { household }\end{array}$ & $\begin{array}{r}\text { Swedish pension } \\
\text { fund }\end{array}$ & $\begin{array}{r}\text { Swedish } \\
\text { foundation }\end{array}$ & $\begin{array}{r}\text { Foreign invest- } \\
\text { ment fund }\end{array}$ \\
\hline Corporate tax & 280 & 280 & 280 & 280 \\
Income tax & 216 & 90 & 0 & 0 \\
Wealth tax & 120 & 0 & 0 & 0 \\
Net return & 384 & 630 & 720 & 720 \\
Tax rate $(\%)$ & 62 & 37 & 28 & 28 \\
\hline
\end{tabular}

Notes: The household is assumed to pay full wealth tax (on $80 \%$ of the market value) on its shareholdings. An individual foreign owner has the same tax burden as a foreign investment fund in those countries where there is no wealth tax on shareholdings and where dividends are taxed at the firm level only; cf. Table 4. 
Table 4 Some Important Aspects of the Taxation of Shareholders in Selected Industrialized Countries, 2000.

\begin{tabular}{|c|c|c|c|c|}
\hline $\begin{array}{l}\text { No taxation of } \\
\text { dividends at the } \\
\text { owner level }\end{array}$ & No wealth tax & $\begin{array}{l}\text { Low wealth tax/large } \\
\text { exemptions and/or low/no } \\
\text { taxation of dividends }\end{array}$ & $\begin{array}{l}\text { No capital gains } \\
\text { tax on long-term } \\
\text { holdings }\end{array}$ & $\begin{array}{l}\text { Capital gains tax }> \\
0 \text { but } \leq 20 \% \text { on } \\
\text { long-term holdings }\end{array}$ \\
\hline Finland & Austria & Finland & Austria & Ireland \\
\hline France & Australia* & France & Belgium & Italy \\
\hline Germany & Belgium & Luxembourg & Denmark & Japan \\
\hline Greece & Canada & Portugal & Germany & Luxembourgł: \\
\hline Italy & Denmark & Spain & Greece & Norway \\
\hline Luxembourg & Germany & Switzerland & Korea* & Poland \\
\hline New Zealand* & Greece & & Luxembourg & Spain \\
\hline Norway & Ireland & & Mexico* & U.S.A. \\
\hline Spain & Italy & & Netherlands & \\
\hline \multirow[t]{7}{*}{ U.K. } & Japan & & Poland & \\
\hline & Netherlands $\dagger$ & & Portugal & \\
\hline & New Zealand & & U.K.\# & \\
\hline & Poland & & & \\
\hline & Portugal & & & \\
\hline & U.K. & & & \\
\hline & U.S.A. & & & \\
\hline
\end{tabular}

Notes: \#Large exemption. $\dagger$ Effective as of $2001 . \$ 50 \%$ of the income tax rate, i.e., a maximum rate of $23 \%$. *Pertains to 1999. The definition of "long-term holdings" varies between 3 months and 5 years. In some instances the situation refers to a representative case.

Sources: The Federation of Swedish Industries, Institutet för Utländsk Rätt and European Tax Handbook (published by KPMG).

\subsection{Capital-Market and Savings Policies}

A policy aimed at high aggregate investment and saving rates and low private wealth accumulation provides a stiff challenge for capital-market policy. These aims were fulfilled in Phase I by a combination of large public savings surpluses, tax policy and a highly regulated capital market. The central government often had an overbalanced budget and the social security system had large surpluses. The mandatory national pension system (ATP) instituted in 1960 transformed the public sector into the most important supplier of credit. Large surpluses were accumulated in the national pension funds, the so-called AP funds. In the early 1970s, the AP funds accounted for 35 percent of total credit supply and close to two thirds of net saving took place in the public sector in the 1960s and 1970s (Pontusson 1992). 
Until the deregulation of credit markets in the mid-1980s, the effective real rate of interest after tax was invariably very low and, in most cases, strongly negative. Hence, the price of capital could not function as an efficient allocative mechanism in capital markets, as investments with a low and even negative social rate of return became privately profitable given that credit was granted.

Saving was either the result of noneconomic considerations as in the public sector, or induced through strong tax incentives within the business sector. The banks provided the household sector with saving incentives by letting bank saving serve as an entry ticket into the highly subsidized housing market. In general, credits were granted through politically determined quotas. Since the real borrowing cost was negative, the granting of a loan implied a subsidy to the firm, where the size of the subsidy was directly proportional to the size of the loan. ${ }^{6}$ Generally, there are strong reasons to believe that a rationed credit allocation system of this type is highly advantageous for large, incumbent firms (SOU 1982:52). In addition, a number of supplementary schemes also tended to favor incumbent firms. ${ }^{7}$

One important consequence of credit-market regulations has been weak saving incentives. This effect was reinforced by the tax system. The desired outcome was to curb individual wealth accumulation. It is clear from Table 5 that household saving in Sweden has been low by international comparison. Since saving is the means by which wealth is accumulated, the effects of this overall policy linger for a long time, even if the incentives for private wealth accumulation are substantially strengthened.

Table 5 Household Net Saving as a Share of Disposable Income in Sweden, OECD and OECD Europe, 1960-97 (percent).

\begin{tabular}{lrrrr}
\hline & $1960-69$ & $1970-79$ & $1980-89$ & $1990-97$ \\
\hline Sweden & 6.1 & 4.0 & 1.1 & 5.4 \\
OECD & 9.7 & 12.1 & 11.2 & $9.8 \dagger$ \\
OECD Europe & 12.0 & 13.6 & 11.6 & $10.9 \dagger$ \\
\hline
\end{tabular}

\footnotetext{
${ }^{6}$ See Jonung (1994) for a detailed examination of Swedish capital-market regulations in the postwar period.

${ }^{7}$ One such arrangement was a so-called "lending back" scheme from the AP fund system, by which employers were allowed to borrow up to half the amount they had paid into the fund during the previous year. The potential for using this credit channel was therefore proportional to the wage bill of the firm.
} 
The low level of household wealth accumulation that resulted from these capitalmarket and tax policies in turn contributed to a deterioration in the conditions for entrepreneurship and start-up activity. The availability of equity financing is a critical factor for both start-ups and the expansion of incumbent firms. In general, the riskier the business, the greater the reliance on equity relative to debt financing. The existence of collateral notwithstanding, a sizeable infusion of equity is often a prerequisite for obtaining credit. In addition, a large infusion of equity by owners signals their belief that the project offers favorable risk and return characteristics, thereby increasing the willingness of banks and other outsiders to grant credit. The smaller and newer the firm, the greater the difficulty for outside financiers to assess the viability and profitability of the proposed investment project. Thus, ceteris paribus, small and newly established firms are more dependent on equity financing as compared to large, well-established firms. There is substantial scientific evidence in support of the idea that an individual's or firm's wealth position has important effects on the probability of becoming an entrepreneur and the propensity to expand (Evans and Leighton 1989; Evans and Jovanovic 1989). Several studies also find a positive relationship between private wealth formation and start-up activity; see, e.g., Blanchflower and Oswald (1998) and Lindh and Ohlsson (1996).

One important part of the regulatory framework during Phase I consisted of impediments to foreign ownership of Swedish firms and Swedish real estate. These rules stipulated that foreign direct investments and acquisitions had to be approved by public authorities and that foreigners were not permitted to acquire real estate. In addition, shares in Swedish companies were divided up into so-called restricted and unrestricted shares; the former could only be acquired by Swedish citizens. ${ }^{8}$ In practice, these rules precluded extensive foreign ownership of Swedish companies until the mid-1980s.

\subsection{Wage-Earner Funds}

A very ambitious plan to transfer most of the privately-owned business sector into collective ownership was developed within the labor movement in the mid 1970s. This wage-earner fund scheme was designed to entail a gradual transfer of ownership of all firms with more than 50 employees to wage-earners as a collective group. Firms would be obligated to issue new shares to the wage-earner funds corresponding to a value of 20 percent of their profits. Thus, the more profitable the firm, the more rapid the transfer of ownership. As an

\footnotetext{
${ }^{8}$ See Reiter (2001) for an account of these regulations.
} 
illustration, assuming a rate of profit of 10 percent, it would take 35 years for the wage-earner funds to obtain a majority equity share in an individual company. The wage-earner equity thus acquired was intended to remain in the firm as working capital.

Since the shares would not be traded, labor's influence on the allocation of investments across firms was not intended to increase - at least not in theory. But it is quite clear that the authors of the plan regarded wage-earner funds as a means of "democratizing" corporate investment decisions of strategic significance for society as a whole. For example, they claimed that wage-earner funds might prevent Swedish multinational firms from moving employment and R\&D abroad (Meidner 1978). These explicit proposals to infringe on private ownership implied a break with the historical compromise. In due course therefore, the wage-earner fund proposals met with unprecedented opposition from capital owners.

Moreover, the original proposal never gained full acceptance within the SocialDemocratic Party itself. Subsequent joint proposals from the LO and the Social Democrats were less radical than the original plan. Politically, all proposals were blocked until the Social Democrats returned to power in 1982. By this time, public opinion had shifted against wageearner funds, but under pressure from the LO, the government implemented a considerably diluted version in 1984. Most importantly, the build-up of wage-earner funds was restricted to seven years. These funds were abolished in 1992 by the then non-socialist government.

\section{The Effects of the Policies Pursued}

We have already pointed out the link between political ideology and the policies pursued. We now address their effects on outcomes. Let us begin by examining the situation at the end of the 1940s. According to calculations in Spånt (1975), households then held 75 percent of all Swedish listed shares. These calculations apply to final owners, which implies that ownership by investment companies and other intermediate owners has been netted out. The final owner categories are households, institutions and foreigners. Private ownership was highly concentrated at this point in time. ${ }^{9}$ This is clearly documented by Lindgren (1953) in a study based on the 1945 Swedish Census. He shows that 6-7 percent of shareholders controlled 6570 percent of the stock-market value. His findings regarding ownership control in the largest companies (more than 500 employees) are of even greater interest in our context. In no less

\footnotetext{
${ }^{9}$ Roine (2000) provides one possible explanation for the design of economic policy as described here. He shows theoretically that if private wealth is very unequally distributed initially, a political coalition will arise between low-income earners and the rich. A prerequisite for this coalition is the introduction of safety valves/breaks in the tax system for those who are rich initially, so they can avoid being substantively affected by an increase in aggregate taxation.
} 
than 60 percent of large firms, a single individual represented the majority of the votes at the shareholders' general meeting. In more than 90 percent of these firms, three or less owners constituted the majority at the shareholders' meeting.

In addition, the same individuals or families frequently held a majority position in a number of firms. Against this background, the then leader of the Communist party C. H. Hermansson (1962) coined the expression "the fifteen families" who, in his view, controlled Swedish industry. This notion was later confirmed by a government commission on ownership concentration (SOU 1967:7) and by Glete (1994). In terms of Shumpeter's (1942) analysis, Swedish industry was - already at this stage - rather close to the point where socialization of the industrial sector would become politically inevitable. As we have discussed at some length, the tax policies initiated at the beginning of the postwar period promoted an increasing institutionalization of business ownership, although it also spurred the development towards increased concentration of ownership and firms.

In the preceding section, we noted that the policy package discouraged wealth accumulation at the household level and strongly favored institutional ownership of the business sector. Figure 1 demonstrates that this policy had a profound impact on ownership structure: during the postwar period, the household ownership share fell sharply while the institutional share rose commensurately.

Figure 1 The Distribution of Ownership of Swedish listed Shares across Ownership Categories, 1950-2000 (percent).

About Here (Enclosed)

Sources: Spånt (1975), Norrman and McLure (1997), Statistics Sweden and OM Stockholm Stock Exchange.

From the perspective of the individual household, the fact that the tax code enhanced the accumulation of retained earnings in firms implied that existing corporate wealth owned by households was locked into incumbent firms. According to traditional financial theory, such within-firm saving should be translated into household wealth through appreciated stockmarket values. In practice, matters did not turn out this way. Until the early 1980s, stockmarket values were extremely depressed, ${ }^{10}$ which in most cases implied that the net worth of Swedish companies greatly exceeded their stock-market value. Södersten (1984) calculates

\footnotetext{
${ }^{10}$ David and Mach (2002) report that stock market capitalization was only 3 percent of GDP in Sweden in 1975 compared to 12 percent for Germany, 30 percent for Switzerland and 48 percent for the US.
} 
that Tobin's $q$ (the stock-market value of the firms divided by their replacement value) was approximately unity in 1960 and that it fell to 60 percent in 1970 and further to 30 percent in 1980. When Tobin's q is below unity there is no incentive to finance investment through new share issues, since that implies wealth destruction. At the same time, there are strong incentives to use internally generated funds to finance investments in incumbents firms, when taxation is high on funds withdrawn from existing firms.

Another indication of low market values is given by the price-earnings ratios for large Swedish companies. The P/E-ratios for firms like Ericsson, Electrolux and Volvo were typically around 2-3 in the early 1970s. Since the regulatory and policy environment induced a development towards increased institutional ownership, the stock-market boom which began in 1979-80 did not fuel household wealth accumulation to any large extent.

Paradoxically, deteriorating conditions for household ownership have been accompanied by increased concentration of private controlling ownership in the largest Swedish firms. During the postwar period, the boards of many large companies in Sweden have been dominated by one family in particular - the Wallenbergs. In a study of the 25 largest companies, Glete (1994) found that the Wallenbergs had a controlling interest in two of these companies in 1925, but that the corresponding figures had risen to five in 1945 and nine in 1990.

While confronted with a sizeable increase in institutional ownership as well as policies aimed at discouraging private ownership, it is enigmatic that a single family has been able to consolidate its dominant position to such an extent. In practice, of course, a controlling interest in a company relies on a smaller share of equity capital over time. The Wallenbergs were much more proficient than other well-established families in taking advantage of the ownership vacuum brought about by far-reaching institutionalization of ownership during the postwar period (Lindgren 1994).

In a political perspective, however, this trend does not necessarily seem inconsistent. In fact, it adheres to the pattern predicted by Schumpeter (1942), whereby private ownership would become increasingly concentrated. According to Schumpeter, concentration of ownership progresses towards a socialist takeover of power, whereas extensive distribution of ownership lends legitimacy to capitalism.

The policy effects relevant to our analysis may be summarized in a number of stylized facts which characterized the business sector in Sweden at the end of Phase I. They indicate that the outcome of overall policy was not only as intended, but also as expected, given the underlying system of rules and regulations: 
- Household saving in Sweden has been very low throughout the postwar period compared to other rich countries. This, in turn, has resulted in low financial wealth per capita relative to other countries; see Tables 5 and Pålsson (1998).

- The institutional ownership share of the business sector was in all likelihood very high by international standards by the late 1980s when the internationalization of business ownership began to take off.

- The foreign ownership share of the Swedish business sector was small until the late 1980s; see Figures 1 and 2.

- Corporate control of the largest firms has been dominated by just a few families (Glete 1994).

- The debt-equity ratio in the Swedish business sector had been rising for a long time and was very high when the deregulation of financial markets began in 1985 (Josefsson 1988).

- The establishment of new firms and small firm activity have been - and probably still are - low by international comparison (Delmar and Davidsson 2000; GEM 2000).

- Large firms eventually became more predominant in Sweden than in almost any other country (Jagrén 1993; Davis and Henrekson 1997) and the willingness to grow among small firms has been weak (Rickne and Jacobsson 1999; Henrekson and Johansson 1999; Davidsson and Henrekson 2002).

- Popular support for a capitalistic, privately owned business sector fell to very low levels (see Section 6).

All things considered, the business sector in Sweden in the early 1980s found itself in a position not far removed from the early postwar visions of the LO and Wigforss. With a corporate sector dominated by a few large firms and sustained by a small and highly concentrated volume of private wealth, socialization à la Schumpeter (1942) probably seemed more like a mere formality than a fundamental change of system. But the course of events was to take another route.

\section{The Turning Point}

Our somewhat stylized account of developments in general, and policy towards the business sector in particular, resembles a straight line that would ultimately lead to socialization of the 
corporate sector in one way or another. The wage-earner funds could be seen as a logical endpoint of that line. Instead their introduction and their subsequent abolishment came to represent a turning point. From among the numerous and complex explanations for this turn of events, we highlight some of the circumstances which are significant in the context of our analysis.

During the late 1970 s the major industrial countries witnessed a renaissance of the market economy. It was precipitated by many factors, including disappointment at the results of extensive public intervention in the west and the failure of the planned economies in the east. ${ }^{11}$ These developments, along with the first signs of collapse of the socialist economies in the Eastern bloc, would have led to increasing isolation if Sweden had continued on a socialist course.

The long period during which large firms had predominated while small firms had been increasingly marginalized came to an end in the late 1970s. Entrepreneurship experienced a global resurgence. The decrease in the average size of firms in the industrialized countries since the 1970s has been documented by, e.g., Brock and Evans (1986), Loveman and Sengenberger (1991) and Acs (1999). There are several reasons why this occurred:

- Coase (1937) used transaction-cost analysis to explain why many activities were carried out more efficiently within a firm than through deliveries between independent firms, i.e., outside the purview of the market. However, technological change in recent decades has resulted in a dramatic reduction in transaction costs in the market, which has led to increased specialization across firms and sharper focus on each firm's core activity. Outsourcing and corporate downsizing are concrete manifestations of this change (Carlsson 1999; Piore and Sabel 1984). These underlying changes have also made it easier for small and new firms to exploit their comparative advantage regarding the introduction genuinely new products and production methods. Still, large firms often excel in increasing productivity in the manufacture of existing products, while totally new products are often produced more efficiently in newly established firms (Baldwin and Johnson 1999; Audretsch 1995).

- Since the 1960s, there has been a sizeable shift away from industries characterized by large firms and establishments (manufacturing, extraction, construction) towards service

\footnotetext{
${ }^{11}$ See Yergin and Stanislaw (1998) for a comprehensive but easily accessible account of this development.
} 
industries where, as a rule, firms and establishments are smaller (see e.g. Davis, Haltiwanger and Schuh 1996).

- In tandem with increased incomes, consumers have come to demand more differentiated products rather than standardized products suitable for large-scale production and distribution (Piore and Sabel 1984; Carree and Thurik 1999).

- Small entrepreneurial firms can often act as crucial agents of change. Such firms are also motivated to grow and, hence, they are likely to play a particularly important role in the growth process (Audretsch 1995).

- The small business sector can also function as an inexpensive mechanism for identifying and developing entrepreneurial and managerial talent (Lucas 1978).

The first two factors reveal that more goods and services than previously were produced more efficiently in smaller firms and establishments - for structural as well as technological reasons. The last three factors are more dynamic. They imply that to a greater extent than earlier, small and new firms are better suited for contributing to technological and organizational renewal. As a result, growth is profoundly manifested by the expansion of small entrepreneurial firms with viable business concepts (Birch and Medoff 1994). It is also likely that the deregulations introduced in Sweden towards the end of the 1970s undermined the monopoly power of well-established firms, thereby generating new business opportunities for entrepreneurs and small companies. To the extent that this is correct, the underpinnings of Schumpeter's theory and Wigforss' vision had been dislodged.

In Sweden, these trends were accompanied by a noticeable change in public opinion regarding the private sector and entrepreneurship. In Table 6 we report the results from two questionnaires where a representative sample of individuals had been asked about their attitudes towards entrepreneurship and business conditions. In 1978, only 30 percent of the respondents thought it was important to encourage entrepreneurship and the formation of firms. In the 1980s, attitudes towards this issue changed dramatically and by the mid-1980s, approximately three-quarters thought this was important. Perhaps even more striking is the fact that in 1978, only 37 percent of the respondents thought business leaders/entrepreneurs were most efficient in running a firm. In the 1990s this had also changed and by 1997, the percentage who thought that business leaders/entrepreneurs were the most efficient was so high that the question had virtually lost its relevance. The reversal in popular attitudes towards self-employment, entrepreneurship and private industry in recent years has been confirmed in a number of studies. Puranen (2001) reports that 78 percent of Swedish men and women aged 19-25 could consider starting their own business. A Swedish opinion poll in 
1998 found that 78 percent of men and 67 percent of women aged 20-24 could consider starting their own business. ${ }^{12} 13$

Table 6 Results from Two Repeated Cross-section Studies of Attitudes towards Entrepreneurship.

Question I: Is it important to encourage entrepreneurship and the formation of new firms? Share of respondents who think it is important:

\begin{tabular}{lrrrrrr}
\hline Year & 1963 & 1967 & 1978 & 1981 & 1985 & 1997 \\
Share (\%) & 50 & 41 & 30 & 72 & 74 & 88 \\
\hline
\end{tabular}

Question II: Who do you think is capable of running a firm most efficiently? Choose between (1) business leaders/entrepreneurs, (2) trade union representatives, and (3) do not know/equally good. Share of respondents who think business leaders/entrepreneurs were most efficient:

\begin{tabular}{lrrrr}
\hline Year & 1978 & 1982 & 1995 & 1997 \\
Share (\%) & 37 & 55 & 80 & 90 \\
\hline
\end{tabular}

Sources: SIFO, Demoskop and The Swedish Employers' Confederation (SAF).

Schumpeter's prediction that popular support for a capitalist private sector would be dislodged by the growing dominance of large firms appears to have prevailed in Sweden until the end of the 1970s. After that, however, there was an about-face in public opinion. As of the early 1980s, hardly any popular support remained for socialization of the corporate sector. Wage-earner funds were introduced in 1984 despite negative public opinion, although the model actually implemented was a half-hearted version of original ambitions. The wageearner funds were probably important also in that they provided the igniting spark for the mobilization among Swedish industrialists in defense of private ownership and entrepreneurship. $^{14}$

Otherwise during the 1980s, Swedish policy proceeded into alignment with a market economy, particularly after financial markets were deregulated. Important aspects of this trend

\footnotetext{
${ }^{12}$ Poll taken by TEMO; reported in the Swedish newspaper Dagens Nyheter, May 30, 1998.

${ }^{13}$ However, it is still unclear whether these positive attitudes will be translated into substantial start-up activity. Delmar and Davidsson (2000), Davidsson and Henrekson (2002) and GEM (2000) find that the number of nascent entrepreneurs relative to the active-age population was still low in Sweden at the end of the 1990s relative to other comparable countries.

${ }^{14}$ Blyth (2001) even claims that this counter-mobilisation is the most important explanation for the turning point. In our opinion this is a gross exaggeration.
} 
in the context of our analysis include a repeal of currency restrictions and gradual removal of the obstacles to foreign acquisition of Swedish firms. But how could this policy reversal be in line with the interests of the Social-Democratic government at the time? This is of course a highly complex issue with no simple answer. As stressed by Jörnmark and Strandberg (2002), the large Swedish multinationals had ample opportunities to circumvent the foreign exchange regulations and the government had already since the 1970s been generous in granting Swedish MNFs the right to acquire foreign exchange for their expansion abroad. Moreover, the deregulation of the credit market in the early 1980s made it necessary to allow insurance companies and other financial investors to buy foreign assets in order to avoid domestic asset inflation. At the same time, these changes put pressure on the capital balance and it became necessary to allow foreigners to invest in Swedish assets as well; in 1989 all remaining foreign exchange controls were lifted. It is unlikely that the people involved in this process at the time were fully aware of the implications for the ownership of Swedish industry in the longer term. ${ }^{15}$

\section{Globalization and Ownership of Swedish Firms}

After the obstacles to foreign acquisition were eliminated and the effects of the globalization process were intensified, foreign ownership in Sweden has grown substantially in recent years. We have already noted the rapid increase in the share of foreign ownership on the Stockholm Stock Exchange during the 1990s, from 8 percent in 1990 to 43 percent in 2001, whereas households' share (excluding mutual funds) has stabilized at around 19-20 percent of the stock-market value.

It should be kept in mind that these statistics only capture one aspect of foreign ownership in the Swedish corporate sector. Even if foreigners own a large proportion of the shares in a Swedish listed company, their direct influence on the way the firm is managed is usually rather limited. The dominant owners (at least in terms of voting rights) are often domiciled in Sweden, and foreign holdings are normally split up among many owners. Influence is altogether different, however, when an entire firm is under foreign ownership. As shown in Figure 2, the number of employees in wholly foreign-owned companies has grown rapidly in Sweden over the last two decades. In 1980, approximately 113,000 Swedes were employed in foreign firms. By 2001, this figure had risen to 520,000 and more than one out of

\footnotetext{
${ }^{15}$ This is confirmed by the then Minister of Finance Kjell-Olof Feldt in an interview by Henrekson on August
} 
five employees in the business sector (21 percent) worked for a foreign firm (ITPS 2002). Until the late 1980s, foreigners established and expanded their own activities in Sweden. But after ASEA merged with Brown Boveri in 1987, to become a Swiss-based company, many often very large - Swedish firms have been acquired by foreign owners. ${ }^{16}$ Strandell (2000) reports that at the end of 1999, manufacturing and services were well represented among the 30 largest foreign-owned companies in Sweden. The dominance of foreign ownership is particularly evident in the pharmaceutical industry, with an ownership share of 86 percent.

Figure 2 Number of Employees in Foreign-Owned Firms in Sweden and Their Share of All Employees in the Swedish Business Sector, 1980-2001.

\section{About Here (Enclosed)}

Sources: Strandell (2000) and ITPS (2002).

The trend is similar in all industrialized countries, but much more pronounced in Sweden. This is manifest in Figure 3, which shows inward and outward foreign direct investment flows as a share of gross capital formation in a number of industrialized countries during the period 1994-99. From the mid-1990s, inward FDIs are very large in Sweden both in an absolute sense and compared to other countries. On average, they correspond to 55 percent of total gross investment. This figure may be compared to a corresponding level of 31 percent in Ireland, the country which is usually mentioned in this context. According to our analysis, this is largely due to the wealth and ownership policies pursued in Sweden, especially during the first postwar phase.

Figure 3 Inward and Outward FDI Flows as a Percentage of Gross Fixed Capital Formation, Average 1994-1999

\section{Enclosed}

Note: Belgium includes Luxembourg. Source: Own calculations based on UNCTAD, World Investment Report and OECD, Employment Outlook (various issues).

$10,2002$.

${ }^{16}$ This of course implies that Swedish MNCs with substantial overseas investment are now themselves in several cases acquired by non-Swedes. 
As a result, the volume of domestic individual wealth in Sweden remained very low in an international comparison; in the mid 1990sfinancial wealth per capita was roughly 20 percent of the US level and 30 percent of the German level (Pålsson 1998). This has precluded Swedish business ownership interests from fully participating in the restructuring of international business, which, in turn, is an essential component of the globalization process.

In many instances, institutional ownership appears to be more appropriate for managing a given firm structure than for aggressively participating in restructuring aimed at enhancing an explicit ownership position. An important aspect of institutional ownership in Sweden is related to the legal rules for tax-exempt family-endowed foundations. As a prerequisite for tax exemption, such foundations are obligated to donate 80 percent of their dividend income to charity. This not only diminishes their financial strength, but is also suspiciously similar to a tax - except that the foundation is able to determine how the "tax" will be used. In any event, the system generates incentive problems. When dynastic ambitions cease to serve as a sufficiently strong incentive, such foundations would no longer be able to maintain their competence as owners to the same degree as those who can freely dispose of their returns.

International procurement of firms takes place by means of a process of portfolio adjustment as well as restructuring through mergers and acquisitions. In both of these areas, dependence on large firms implies that as compared to other countries, Sweden has been more involved in the globalization process (see Figure 3). In terms of portfolio adjustment, a foreign investor will give priority to large companies. They usually offer the best information and transparency (Dahlquist and Robertsson 2001), and it is relatively easy to compare large companies with their counterparts in other countries. Moreover, when diversifying, it is likely that an investor has to confine himself to a limited number of international firms; it thus seems preferable to stick to large companies.

In terms of restructuring, large Swedish companies are highly internationalized, with operations in many different countries. As a result, they are engaged in the extensive worldwide restructuring process prompted by internationalization and globalization. This, in turn, enhances foreign ownership in the Swedish corporate sector. The relatively small volume of domestic wealth (Pålsson 1998) makes it difficult for Swedish ownership to assert itself in the process. In addition, since tax rules still favor foreign ownership, Swedish-owned firms tend to be undervalued in relation to their foreign counterparts. It is therefore not surprising that owners of Swedish firms find it hard to resist takeover offers, even from relatively similar companies. 
On the whole, we anticipate that within a few years, the majority of large companies in Sweden will be foreign owned. Given the domestic dominance of large firms, Sweden will soon find itself among those industrialized economies with the greatest degree of foreign ownership. Over a comparatively short period of time, the trend in the Swedish business sector has shifted - from negligible foreign ownership and a long-run vision of socialist ownership, to a rapidly increasing share of foreign ownership and influence.

At the same time there has been a dramatic shift in corporate governance, i.e., the mechanisms by which corporations and their managers are governed. Until recently, Swedish firms operated in a corporatist environment where capital markets and shareholder value played a subordinate role. The change in ownership that we have described is part of a major restructuring of the Swedish business sector orchestrated by the capital market, by means of mergers and takeovers. The situation in Sweden is in many ways similar to that in the U.S. as described in Holmstrom and Kaplan (2001). The difference is that the mergers and takeovers in Sweden have mainly been of the cross-border type. It seems as if the other corporatist economies of Europe have clung to their established patterns of corporate governance to a much larger extent (Kluger 2001), the only exception being Switzerland (David and Mach 2002).

\section{Concluding Remarks}

The dramatic transformation of ownership policy and ownership structure analyzed here implies profound structural change, with extensive effects in the economic as well as the political sphere. We have attempted to survey this development and explain the underlying impulses.

The key issue addressed in this essay has been the factors which generated the highly pronounced break in the trend, around the mid-1980s, regarding the ownership structure of the Swedish business sector. Our conclusion is that the policy switch which occurred internationally during the 1980s had a significant effect, but an important additional factor in Sweden, however, was the reciprocal relation between earlier ownership policy, supported by a long-run socialist vision, and international deregulation during the 1980s. The policy initially formulated on the basis of this socialist vision "packaged" the Swedish business sector in such a way that it became susceptible to foreign takeover. The opportunity was provided as soon as deregulation towards international markets had occurred. This effect is 
due to three main aspects of the policies pursued during Phase I: (i) individual wealth accumulation was discouraged; (ii) institutional ownership was stimulated relative to individual ownership; and (iii) overall policy magnified the (already strong) dependence on large companies in Sweden. The mirror image is that new and small firms were at a relative disadvantage. In addition, there were strong obstacles to foreign ownership of Swedish companies. Hence, as soon as financial markets had been deregulated, the same factors that paved the way for socialization and/or collectivization of ownership in a closed capital market facilitated foreign takeover of the Swedish business sector.

We have not investigated the effects of the development outlined here. This provides a broad field for further research. For the time being, we point out three areas where the effects could be significant.

Productivity and economic efficiency. There are two principal reasons to expect that increased foreign ownership will give rise to higher productivity and greater efficiency in firms. First, it is well documented that the transfer of technology from the home country to the host country usually occurs through multinational companies; see, e.g., Blomström and Kokko (1998) and Baldwin, Braconier and Forslid (1999). As a result, the R\&D investments of Swedish multinationals have generated increased productivity in their foreign subsidiaries (Forss 1996). The inflow of direct investments implies that Sweden is now in a position to be on the receiving end of this international transfer of technology.

In general, the greater capital mobility inherent in foreign ownership can be counted on to increase the efficiency of investments, thereby contributing to higher productivity in the economy. In a study of the effects of takeovers in Sweden, Modén (1998) found that productivity had risen more in cases where the units had been acquired by foreigners as compared to takeovers by Swedish investors.

Decorporatization of Sweden. During the postwar period, corporatism has been a noteworthy feature of the Swedish economy. Centralized wage bargaining between employers and unions, as well as informal tripartite negotiations between the government, employers and unions have been significant in this context. Such a model cannot work without a certain amount of homogeneity and national support on the employers' side. ${ }^{17}$ Increasingly widespread international ownership of the Swedish business sector will eliminate these prerequisites. Internationalization can be expected to contribute to further decorporatization of Sweden. There are already a number of instances where the controlling owners have

\footnotetext{
${ }^{17}$ Extensive decorporatization of Swedish society had already begun during the 1980s; see Rothstein (2002) and Reiter (2001).
} 
voluntarily given up the privilege of having shares with higher voting power (SKF, Electrolux) in order to boost the valuation of the firm. These are important examples of contractual (rather than formal) convergence (Gilson 2000). Moreover, ongoing case studies (De Geer, Borglund and Frostensson 2002) indicate that a foreign takeover of a Swedish firm is likely to lead to substantial changes in the internal business culture.

Convergence in other policy areas. We have mainly discussed convergence in ownership policies. The idea of the Washington consensus and a general convergence towards the Anglo-Saxon paradigm refers to economic policy as a whole. There are, however, strong links between ownership policies and corporate governance on the one hand and general economic policy on the other. Increased internationalization of the business sector in a country leads to greater sensitivity regarding the differences among countries in terms of corporate rules and regulations. In an internationalized environment, firms have considerable freedom to choose the most economically advantageous location for their activities.

Theoretically, this will limit national governments' prospects for taxing and regulating firms; it might even lead to institutional competition between countries. Such competition would obviously be a strong force in the convergence of economic policy in general.

The Swedish model of our Phase 1 could clearly be classified as a are coordinated market economy (CME). The rapid globalization of the Swedish business sector implies that the Swedish corporate governance regime has approached the Anglo-Saxon or liberal market economy (LME) model. A pertinent question then is whether this will lead to more general adaptation to Anglo-Saxon policies. ${ }^{18}$ So far, this remains an open question. In various areas, Sweden has adapted its policy to a more market liberal course. ${ }^{19}$ In other areas, the old policies prevail. The size of the public sector is still extremely large, to take one example. The current political trend is to hold on to what is left of the old Swedish model. The ultimate outcome will be determined by how well the new liberal production regime performs alongside the ambitious welfare state still in place in Sweden. However, it seems reasonable to hypothesize that the current system, combining an almost fully liberalized market for corporate control with perhaps the most highly regulated labor market regime in the industrialized world (Hall and Soskice 2001), gives rise to a great deal of tension and the degree of tension is unlikely to subside.

\footnotetext{
${ }^{18}$ For a discussion of the interrelationship between production regimes and general policy regimes, see Kitschelt et al. (1999).

${ }^{19}$ See Davidsson and Henrekson (2002)
} 


\section{References}

Acs, Z. (ed.), (1999), Are Small Firms Important? Their Role and Impact. Dordrecht: Kluwer.

Agnblad, J., Berglöf, E., Högfeldt, P. and Svancar, H. (2001), ”Ownership and Cotrol in Sweden: Strong Owners, Weak Minorities, and Social Control." In Barca, F. and Becht, M. (eds.), The Control of Corporate Europe. Oxford: Oxford University Press.

Audretsch, D.B. (1995), Innovation and Industry Evolution. Cambridge, MA: MIT Press.

Audretsch, D.B. and Thurik, A.R. (2000), "Capitalism and Democracy in the $21^{\text {st }}$ Century: From the Managed to the Entrepreneurial Economy." Journal of Evolutionary Economics, Vol. 10, No. 1, 17-34.

Baldwin, J.R. and Johnson, J. (1999), ’Entry, Innovation and Firm Growth.” In Acs, Z.J. (ed.), Are Small Firms Important? Their Role and Impact. Dordrecht: Kluwer.

Baldwin, R., Braconier H. and Forslid R. (1999), "Multinationals, Endogeneous Growth and Technological Spillovers: Theory and Evidence.” CEPR Discussion Paper No. 2155.

Birch, D.L. and Medoff, J. (1994), "Gazelles.” In Solmon, L.C. and Levenson, A.R. (eds.), Labor Markets, Employment Policy and Job Creation. Boulder and London: Westview Press.

Blanchflower, D.G. and Oswald, A.J. (1998), “What Makes an Entrepreneur?” Journal of Labor Economics, Vol. 16, No. 1, 26-60.

Blomström M. and Kokko A. (1998), "Multinational Corporations and Spillovers." Journal of Economic Surveys, Vol. 12, No. 3, 247-277.

Blyth, M. (2001), “The Transformation of the Swedish Model.” World Politics, Vol. 54, No. 1, 1-26.

Brock, W.A. and Evans, D.S. (1986), The Economics of Small Firms. New York: Holmes \& Meier.

Carlsson, B. (1999), ’Small, Business, Entrepreneurship, and Industrial Dynamics.” In Acs, Z.J. (ed.), Are Small Firms Important? Their Role and Impact. Dordrecht: Kluwer.

Carree, M. and Thurik, A.R. (1999), "Industrial Structure and Economic Growth." In Audretsch, D.B. and Thurik, A.R. (ed)., Innovation, Industry Evolution and Employment. Cambridge, MA: Cambridge University Press.

Coase, R.H. (1937), ’The Nature of the Firm.” Economica, Vol. 4, No. 4, 386-405.

Dahlquist, M. and Robertsson, G. (2001), ’Direct Foreign Ownership, Institutional Investors, and Firm Characteristics." Journal of Financial Economics, Vol. 59, No. 3, 413-440.

David, T. and Mach, A. (2002), "Institutionalisation and Questioning of Ownership Restrictions in Switzerland and Sweden." Paper presented at the $6^{\text {th }}$ annual meeting of the European Business History Association, Helsinki, August 22-24.

Davidsson, P. and Henrekson, M. (2002) "Determinants of the Prevalence of Start Ups and High-Growth Firms." Small Business Economics, Vol. 19, No. 2, 81-104.

Davis, S.J., Haltiwanger, J. and Schuh, S. (1996), Job Creation and Destruction. Cambridge, MA: MIT Press.

Davis, S.J. and Henrekson, M. (1997), ”Industrial Policy, Employer Size and Economic Performance in Sweden.” In Freeman, R.B., Topel, R. and Swedenborg, B. (eds.), The Welfare State in Transition. Chicago: University of Chicago Press.

De Geer, H., Borglund, T. and Frostensson, M. (2002), ”Anglosaxification of Swedish Business.” Manuscript. Centre for Ethics and Economics, Stockholm School of Economics.

Delmar, F. and Davidsson, P. (2000), "Who Starts New Firms in Sweden: How Many Are They and Who Are They?” Entrepreneurship \& Regional Development, Vol. 12, No. 1, 1-23.

Evans, D.S. and Jovanovic, B. (1989), ”An Estimated Model of Entrepreneurial Choice under Liquidity Constraints." Journal of Political Economy, Vol. 97, No. 4, 808-827.

Evans, D.S. and Leighton, L.S. (1989), "Some Empirical Aspects of Entrepreneurship." American Economic Review, Vol. 79, No. 3, 519-535.

Fehn, R. and Meier, C.-P. (2001), “The Positive Economics of Labor Market Rigidities.” Kyklos, Vol. 54, No. 4, 
557-590.

Feldstein, M. (2000), “"Aspects of Global Economic Integration: Outlook for the Future.” NBER Working Paper No. 7899.

Forss, G. (1996), R\&D and Technology Transfer by Multinational Enterprises. Ph. D. Dissertation. Stockholm: IUI.

Freeman, R.B. (2000), "Single Peaked vs. Diversified Capitalism: The Relation between Economic Institutions and Outcomes." NBER Working Paper No. 7556.

Galbraith, J.K. (1956), American Capitalism: The Concept of Countervailing Power. Boston: Houghton Mifflin.

Galbraith, J.K. (1967), The New Industrial State. London: Hamish Hamilton.

Garrett, G. (2000), “Globalization and Government Spending around the World.” Mimeo. Yale University: Department of Political Science..

Gilson, R.J. (2000), "Globalizing Corporate Governance: Convergence of Form or Function.” Columbia Law School, The Center for Law and Economic Studies, Working Paper No. 192.

Glete, J. (1994), Nätverk i näringslivet. Stockholm: SNS Förlag.

GEM (2000), Global Entrepreneurship Monitor. Kaufman Center for Entrepreneurial Leadership.

Grosskopf, G., Rabe, G. and Johansson, G. (1997), Det svenska skattesystemet. Stockholm: Norstedts Juridik.

Hall, P.A. and Soskice, D. (2001), “An Introduction to Varieties of Capitalism.” In Hall, P.A. and Soskice, D. (eds.), Varieties of Capitalism. Oxford: Oxford University Press.

Hansmann, H. and Kraakman, R. (2000). "The End of History for Corporate Law." Yale Law School, Law and Economics Working Paper No 235.

Henrekson, M. and Jakobsson, U. (2001), "Where Schumpeter was nearly Right - the Swedish Model and Capitalism, Socialism and Democracy.” Journal of Evolutionary Economics, Vol. 11, No. 3, 331-358

Henrekson, M. and Johansson, D. (1999), "Institutional Effects on the Evolution of the Size Distribution of Firms.” Small Business Economics, Vol. 12, No. 1, 11-23.

Hermansson, C.-H. (1962), Monopol och storfinans. Stockholm: Arbetarkulturs förlag.

Hernes, G. (1991), ”The Dilemmas of Social Democracies: The Case of Norway and Sweden." Acta Sociologica, Vol. 34, No. 2, 239-260.

Holmstrom, B. and Kaplan, S. (2001), "Corporate Governance and Merger Activity in the United States: Making Sense of the 1980s and 1990s." Journal of Economic Perspectives, Vol. 15, No. 2, 121-144.

ITPS, Swedish Institute for Growth Policy Studies

(2002), Foreign-owned Enterprises 2001, S2002:007. Stockholm.

Jagrén, L. (1993), ’De dominerande storföretagen.” In Den långa vägen. Stockholm: The Research Institute of Industrial Economics.

Johansson, A.L. and Magnusson, L. (1998), LO andra halvseklet. Fackföreningsrörelsen och samhället. Stockholm: Atlas.

Jonung, L. (1994), ”The Rise and Fall of Credit Controls: The Case of Sweden, 1939-89.” In Bordo, M.D. and Capie, F. (eds.), Monetary Regimes in Transition. Cambridge: Cambridge University Press.

Josefsson, M. (1988), ’Börsbolagen 1987 - en jämförelse med tidigare år.” Skandinaviska Enskilda Banken Quarterly Review, Vol. 17, No. 4, 76-91.

Jörnmark, J. and Strandberg, U. (2002), “Corporatism and the Wall Street Shuffle: The Reluctant Deregulation of the Swedish Capital Market." Unpublished paper. An earlier version of this paper was presented at the conference Small States in World Markets - Fifteen Years Later. Göteborg, Sweden, September 27-29.

Katzenstein, P. (1985), Small States in World Markets. Ithaca, NY: Cornell University Press.

Kitschelt, H., Lange, P., Marks, G. and Stephens, J.D. (eds.), (1999), Continuity and Change in Contemporary Capitalism. Cambridge and New York: Cambridge University Press.

Kluger, (ed.), (2001), Corporate Governance and Economic Performance. Oxford: Oxford University Press. 
Korpi, W. (1982), “The Historical Compromise and Its Dissolution.” In Rydén, B. and Bergström, V. (eds.), Sweden: Choices for Economic and Social Policy in the 1980s. London: George Allen \& Unwin.

Långtidsutredningen (1982), Tillväxt eller stagnation? Stockholm: Allmänna Förlaget.

Lindgren, G. (1953), "Shareholders and Shareholder Participation in the Larger Companies' Meetings in Sweden." Weltwirtschaftliches Archiv, Vol. 71, No. 2, 281-298.

Lindgren, H. (1994). "The Comparative Advantages of Business Groups: Some Swedish Evidence.” In Dritsas, M. and Gourvish, T. (eds.), European Enterprise: Strategies of Adaptation and Renewal in the Twentieth Century. Athens: Trochalia Publications.

Lindh, T. and Ohlsson, H. (1996), "Self-Employment and Windfall Gains: Evidence from the Swedish Lottery." Economic Journal, Vol. 106, No. 439, 1515-1526.

LO (1951), Fackföreningsrörelsen och den fulla sysselsättningen. Stockholm. (Published in English in 1953 as Trade Unions and Full Employment. London: George Allen \& Unwin.)

Loveman, G. and Sengenberger, W. (1991), ”The Reemergence of Small-Scale Production: An International Comparison.” Small Business Economics, Vol. 31, No. 1, 1-37.

Lucas, R.E., Jr. (1978), “On the Size Distribution of Business Firms.” Bell Journal of Economics Vol. 9, No. 3, 508-523.

Norrman, E. and McLure, C.E. (1997), ”Tax Policy in Sweden.” In Freeman, R.B., Topel, R. and Swedenborg, B. (eds.), The Welfare State in Transition. Chicago: University of Chicago Press.

Meidner, R. (1978), Employee Investment Funds. An Approach to Collective Capital Formation. London: George Allen \& Unwin.

Modén, K.-M. (1998), "Foreign Acquisitions of Swedish Companies - Effects on R\&D and Productivity." Working Paper 1998/3, Invest in Sweden Agency, Stockholm.

Pålsson, A.-M. (1998), “De svenska hushållens sparande och förmögenheter 1986-1996.” Mimeo. Department of Economics, Lund University.

Piore, M. and Sabel, C. (1984), The Second Industrial Divide. New York: Basic Books.

Pontusson, J. (1992), The Limits of Social Democracy. Investment Politics in Sweden. Ithaca: Cornell University Press.

Puranen, B. (2001), The Nineties Report. Available [online]: www.bikupan.se [February 25, 2001].

Reiter, J. "Financial Globalisation, Ownership and the End of Swedish Corporatism." Paper presented at the conference Small States in World Markets - Fifteen Years Later. Göteborg, Sweden, 27-29 September, 2001. New Political Economy, forthcoming.

Rickne, A. and Jacobsson, S. (1999), "New Technology-Based Firms in Sweden.” Economics of Innovation and New Technology, Vol. 8, No. 2, 197-223.

Roine, J. (2000), “Tax Avoidance, Redistribution and Voting.” Mimeo. Department of Economics, Stockholm University.

Rothstein, B. (2002), "Sweden: Social Capital in the Social Democratic State: The Swedish Model and Civil Society." In Putnam R.D. (ed.). Democracies in Flux. Political Culture as a Condition for Democracy. Oxford: Oxford University Press.

Schumpeter, J.A. (1942), Capitalism, Socialism and Democracy. New York: George Allen \& Unwin.

Södersten, J. (1984), "Sweden." In King, M.A. and Fullerton, D. (eds.), The Taxation of Income from Capital. A Comparative Study of the United States, the United Kingdom, Sweden and West Germany. Chicago: University of Chicago Press.

Södersten, J. (1993), "Sweden.” In Jorgenson, D.W. and Landau, R. (eds.), Tax Reform and the Cost of Capital. An International Comparison. Washington D.C.: Brookings.

Soskice, D. (1999), "Divergent Production Regimes: Coordinated and Uncoordinated Market Economies in the 1980s and 1990s.” In Kitschelt, H., Lange, P., Marks, G. and Stephens, J.D. (eds.), Continuity and Change in Contemporary Capitalism. Cambridge and New York: Cambridge University Press 
SOU 1967:7, Ägande och inflytande inom det privata näringslivet. Koncentrationsutredningen. Stockholm: Allmänna Förlaget.

SOU 1982:52, En effektivare kreditpolitik. Betänkande från Kreditpolitiska utredningen Stockholm: Allmänna Förlaget.

SOU 1986:23, Aktiers röstvärde. Betänkande av röstvärdeskommittén. Stockholm: Liber.

Spånt, R. (1975), Förmögenhetsfördelningen i Sverige. Stockholm: Prisma.

Steinmo, S. (2001), "Bucking the Trend? Social Democracy in a Global Economy: The Swedish Case Up Close." Paper presented at the conference Small States in World Markets - Fifteen Years Later. Göteborg, Sweden, 27-29 September 2001. New Political Economy, forthcoming.

Strandell, A.-C. (2000), ’Utlandsägda företag." In Svenskt näringsliv och näringspolitik 2000. Stockholm: NUTEK Förlag.

Sundin, A. and Sundqvist, S.-I. (2001), Ägarna och makten. Stockholm: SIS Ägarservice.

Tinbergen, J. (1961),’Do Communist and Free Economies Show Converging Patterns?" Soviet Studies, Vol. 12, No. 3, 333-341.

UNCTAD (1999), World Investment Report 1999. New York: United Nations.

Yergin, D. and Stanislaw, J. (1998), The Commanding Heights. New York: Simon \& Schuster.

Wigforss, E. (1952), Socialism i vår tid. Stockholm: Tidens förlag.

Wigforss, E. (1956), Efter välfärdsstaten. 
Figure 1 The Distribution of Ownership of Swedish listed Shares across Ownership Categories, 1950-2000 (percent)

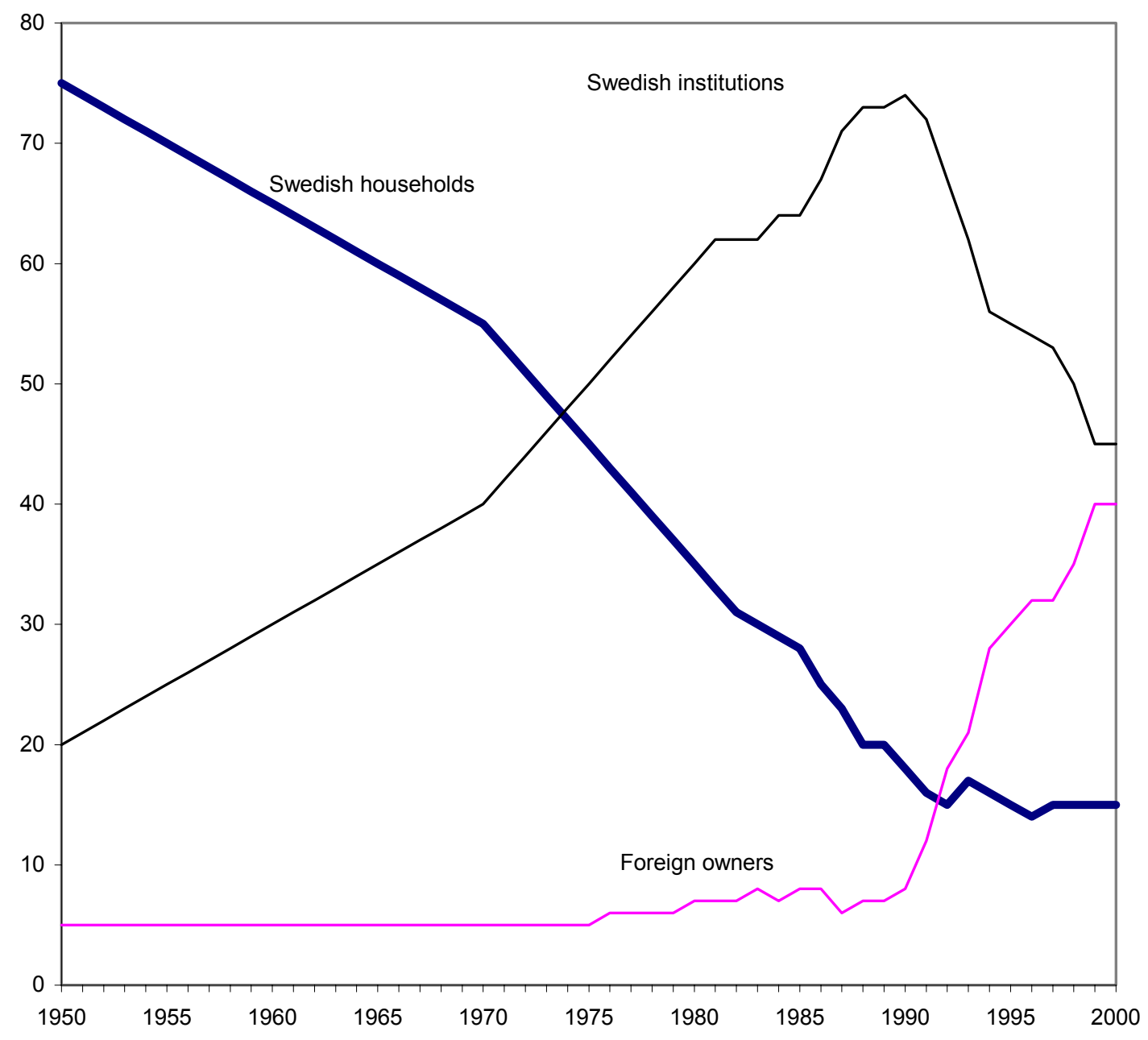


Figure 2 Number of Employees in Foreign-Owned

Firms in Sweden and Their Share of All Employees in the Swedish Private Sector, 1980-2001

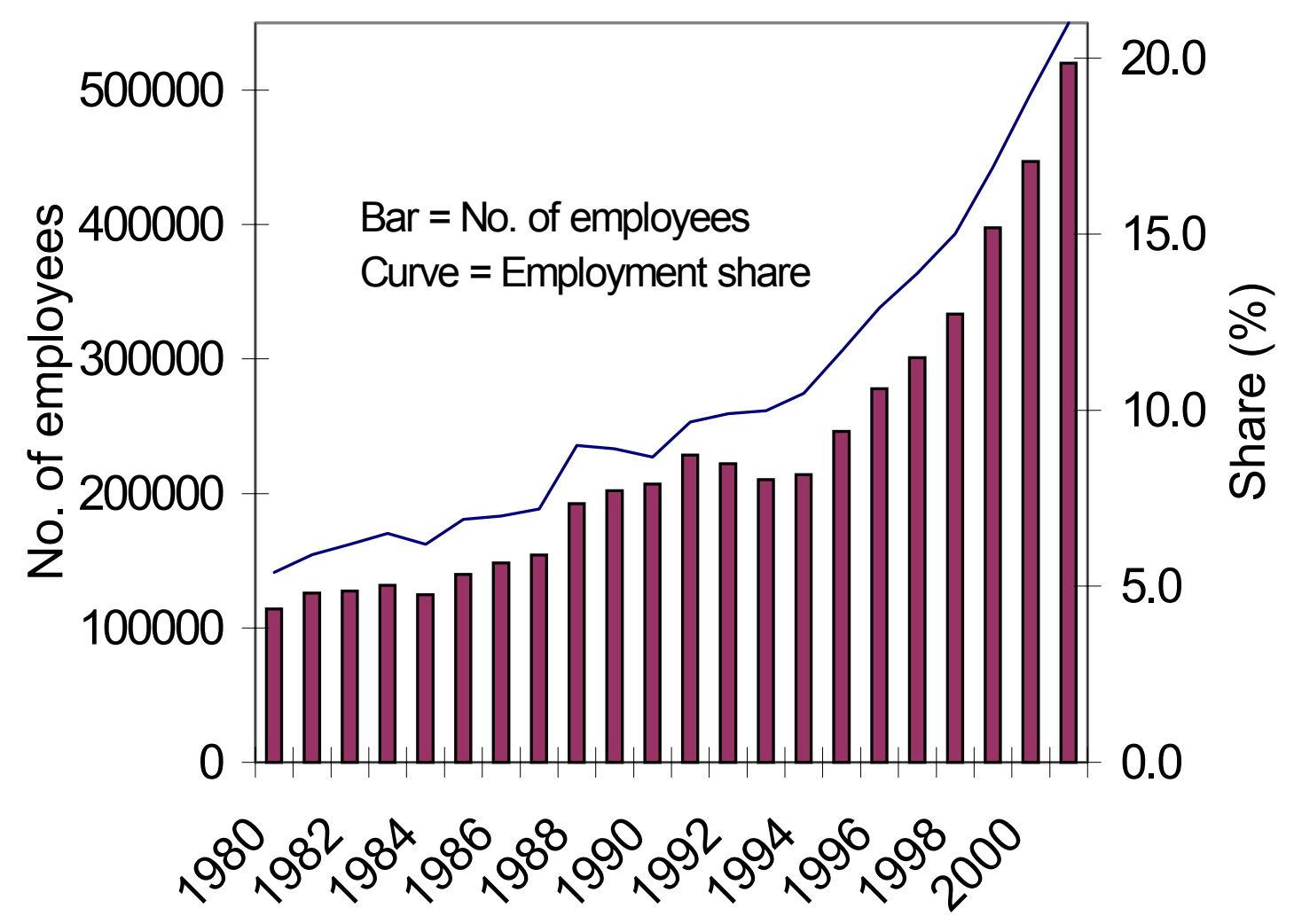


Figure 3 Inward and outward FDI flows as a percentage of gross fixed capital formation average 1994--1999

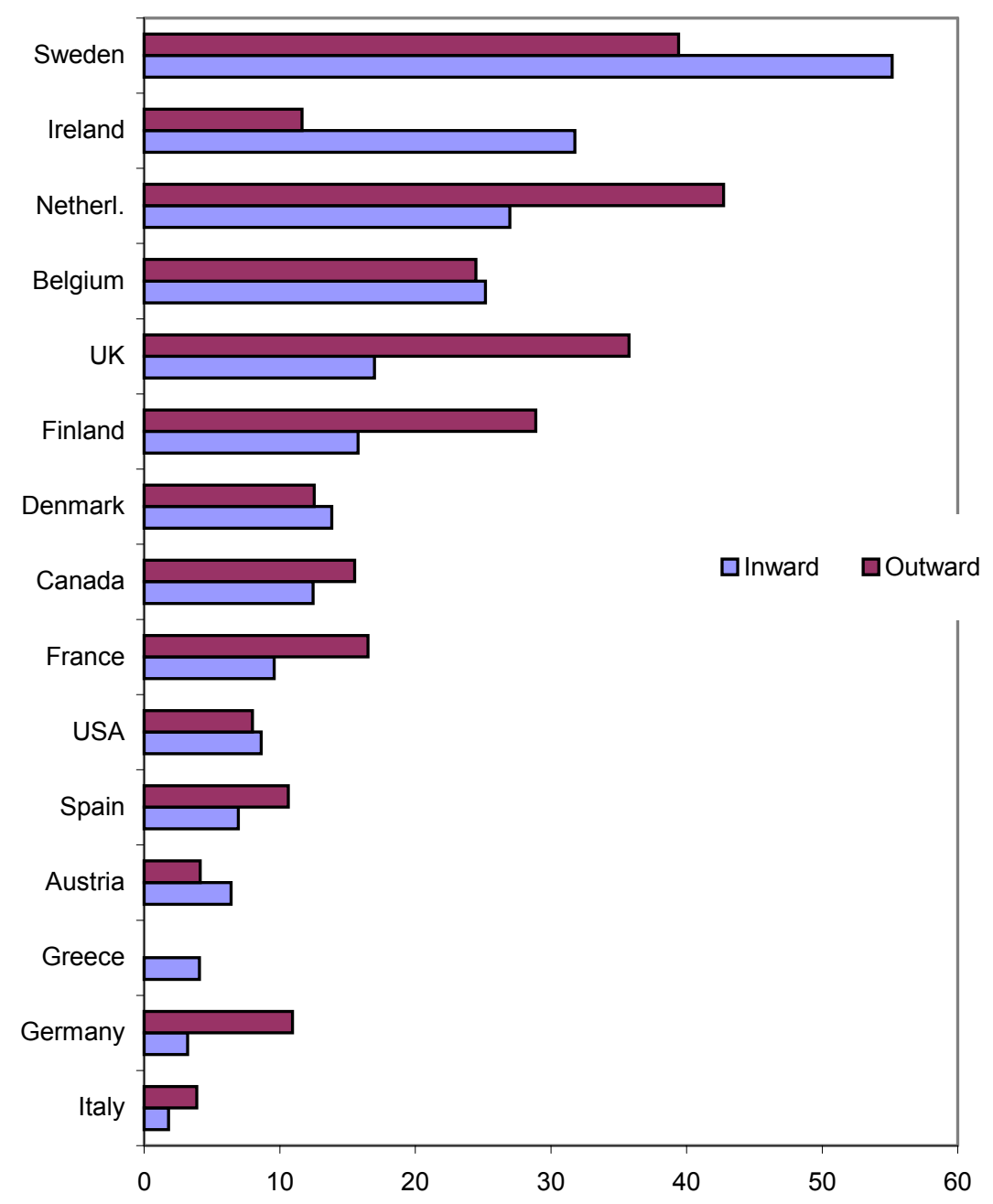

